\title{
Doktora deneyiminin öğrenciler ve akademisyenler açısından değerlendirilmesi
}

\section{Assessing Ph.D. experience from the perspectives of students and academics}

Gönderim Tarihi / Received: 24.03.2021

Kabul Tarihi / Accepted: 03.12.2021

Doi: https://doi.org/10.31795/baunsobed.902795
Derya DEMIRDELEN ALRAWADIEH**1

Hasibe YAZIT ${ }^{2}$

ÖZ: Öğrencilerin akademik gelişimindeki son aşama olan doktora eğitim sürecinde öğretim üyeleri ve öğrenciler arasındaki uyumun sağlanması, eğitimin etkinliği ve verimliliği açısından oldukça önemlidir. $\mathrm{Bu}$ açıdan, öğretim üyelerinin doktora öğrencilerine ve turizm eğitimine; doktora öğrencilerinin de öğretim üyelerine ve turizm eğitime bakış açısını değerlendirmek mevcut durumu ortaya koyabilmek açısından gereklidir. Araştırmanın amacı, turizm alanında doktora öğrenimi veren öğretim üyeleriyle, turizm alanında eğitim alan doktora öğrencilerinin görüş ve düşüncelerini ortaya koymaktır. Bu amaçla katılımcılarla (20 öğretim üyesi ve 20 doktora öğrencisi) 2020 yılının sonlarında derinlemesine görüşmeler yapılarak veriler toplanmıştır. Veri toplama sürecinde kolayda ve kartopu örneklem yöntemine başvurulmuş, COVID-19 salgını nedeniyle tüm görüşmeler uzaktan (telefon veya zoom üzerinden) gerçekleştirilmiş ve elde edilen veriler içerik analizi yöntemiyle çözümlenmiştir. Bulgular; doktora düzeyinde ders veren öğretim üyelerinin genel olarak öğrencilerden memnun olduklarını ortaya koysa da, öğretim üyeleri doktora öğrencilerine yönelik bazı eksikliklerin varlığı konusunda hemfikirdir. $\mathrm{Bu}$ noktada öğretim üyeleri tarafından, öğrencilerin en sık araştırma yöntemleri ve akademik yazım konusundaki yetersizliklerinin vurgulandığı görülmektedir. Doktora öğrencilerinden elde edilen bulgularda ise, öğrencilerin genel olarak öğretim üyeleriyle iyi ve uyumlu bir ilişki yürüttükleri, ancak eğitim kalitesinden tam anlamıyla doyum elde edemedikleri sonucu ortaya çıkmıştır. Mevcut çalışmanın, özellikle turizmde doktora eğitim deneyimine yönelik sınırlı olan alan yazına teorik katkı sağlayacağ düşünülmektedir. Doktora eğitim sürecinin etkinliği ve verimliliği açısından uygulamaya yönelik olarak ise doktora ders havuzunun güncellenmesi, akademik gelişimle doğru orantılı derslerin eklenmesi, öğretim üyelerinin öğrenciler açısından yol gösterici olması ve öğrencilerin de akademik gelişime odaklanmaları önerilmektedir.

Anahtar Kelimeler: Doktora öğrenimi, Lisansüstü öğrenciler, Öğrenci-akademisyen ilişkisi

ABSTRACT: Ensuring harmony between faculty members and students is very important during Ph.D. education, the final stage in the academic development of students. In this respect, examining the perceptions of faculty members and tourism Ph.D. students towards each other is necessary to understand the current conditions in tourism higher education. In late 2020, total of 40 interviews (20 with faculty members and 20 with Ph.D. students) were conducted by phone and zoom due to Covid-19 and data obtained were content analysed. A convenience sampling as well as a snowball sampling techniques were used. Results indicate that while faculty members are generally satisfied with their $\mathrm{Ph} . \mathrm{D}$. students, they identify some shortcomings including weakness in terms of research methods and academic writing. From the students' standpoint of view, however, a good and harmonious relationship with their faculty members is emphasized, but they show concern regarding the quality of education they receive. The present study makes a theoretical contribution to the limited literature on Ph.D. tourism education experience. In terms of the effectiveness and efficiency of the Ph.D. education, it is recommended to update the Ph.D. curricula, add courses that are directly relevant to the student's academic development, provide adequate mentorship for the students, and more engagement by students with academic development.

Keywords: Ph.D. education, Post-graduate students, Students-academician relationship

\footnotetext{
** Sorumlu Yazar / Corresponding Author

${ }^{1}$ Dr. Öğr. Üyesi, İstanbul Ayvansaray Üniversitesi/Plato Meslek Yüksekokulu/Seyahat, Turizm ve Eğlence Hizmetleri Bölümü, deryademirdelen@ayvansaray.edu.tr, https://orcid.org/0000-0002-7554-2256

${ }^{2}$ Dr. Öğr. Üyesi, Sinop Üniversitesi/Turizm İşletmeciliği ve Otelcilik Yüksekokulu/Gastronomi ve Mutfak Sanatları Bölümü, hyazit@sinop.edu.tr, https://orcid.org/ 0000-0003-1055-5192
} 


\section{EXTENDED ABSTRACT}

\section{Literature review}

Ph.D. education is regarded as an important process in order to preper qualified manpower and it contributes to the development of science (Özmen \& Aydın Güçlü, 2013). In line with the importance of Ph.D. education, research on Ph.D. education in both national (Saracaloğlu, 2008; Özmen \& Aydın Power, 2013; Limon \& Durnal1, 2018) and international (Overall et al., 2011; Brush et al., 2013; Hill \& Conceição, 2020) literature has been conducted in many disciplines.

Although there is considerable researche on the $\mathrm{Ph} . \mathrm{D}$ education in different disciplines; only few studies within the tourism literature have been identified (Okumus and Yagci, 2006; Çakıc1, 2006; Li and Qi, 2019; Qi and Li, 2020; Li et al., 2021; Yazıt and Demirdelen-Alrawadieh, 2021; Ajanovic and Chizel, 2021). Although these studies draw attention to the importance of the Ph.D in tourism, studies that offer a bilateral view on Ph.D education in tourism are very limited (eg Çakıc1, 2006). In this sense, the present study reveals the educational experience of the students who do Ph.D in the field of tourism, and also determines the views and thoughts of the students towards Ph.D education.

\section{Methodology}

The aim of this study is to examine the views and perceptions of faculty members who are engaged in Ph.D. education in the field of tourism and Ph.D. students in the field of tourism. For this purpose, indepth interviews were conducted. An interview protocol was developed for both academicians who teach at the Ph.D level and students who read for their Ph.D in tourism to determine their experiences towards Ph.D. Interview protocols for both samples were developed based on a detailed literature review on Ph.D education (Golde \& Dore, 2001; Çakıc1, 2006; Saracaloğlu, 2008; Limon \& Durnal1, 2018; Li \& Qi, 2019; Qi \& Li, 2020). A total of 40 interviews (20 with faculty members and 20 with Ph.D. students) were conducted by phone and zoom due to Covid-19 and data obtained were content analysed. Using the convenience and snowball sampling method, the data collection process was completed between August 1, 2020 and September 3, 2020. Within the scope of this research, ethical approval was obtained from Sinop University Human Research Ethics Committee (2020/93).

\section{Findings and discussion}

This part has been evaluated under two headings (in terms of faculty members and Ph.D students). First, faculty members teaching at the Ph.D level emphasized research methods and academic writing, especially based on the academic deficiencies of Ph.D students. Moreover, the difficulties in reconciling theory and practice, the bad effects of the memorization system, the students' lack of openness to development, the lack of time to read and research, the lack of research-curiosity of the students, the carelessness shown in homework, and the lack of foreign language were highlighted.

Faculty members also stated that students who read for their Ph.D are driven by the need of overcoming professional difficulties; they stated that compelling reasons such as the anxiety of finding a job, seeing academics as a way out or a job field are an obstacle to being a quality researcher. For all these reasons, the fact that Ph.D students cannot focus on the education process, and even if they do, do not allocate enough time to the academy due to personal or professional difficulties exacerbates the possible problems. Most of the faculty members state that Ph.D students have the right to choose an advisor. However, the problem here may be that the number of $\mathrm{Ph} . \mathrm{D}$ students defined on a faculty member is quantitatively higher. Because there are more students than they should be, it can cause counseling not to be done properly and some problems to arise. For this reason, some participants stated that students have the right to choose a counselor as long as the conditions allow.

In the second part of the study, the opinions of Ph.D students were taken. In this context, it has been determined why Ph.D students choose Ph.D education in tourism. Although there are different opinions, the result is a common denominator: 'Being an academician'. While current findings confirm that the benefit from $\mathrm{Ph}$.D level education is multifaceted; It cannot be said that all students agree on this process. Especially, the rate of those who evaluate the benefit obtained in this process and the quality of education 
received as average or below the average is quite high. In other words, the findings were united in the view of improving tourism education given at the Ph.D level.

\section{Results and recommendations}

A general perspective on Ph.D education in the field of tourism in Turkey is presented with the findings revealed by examining the views of tourism students and lecturers at the Ph.D level. Some of the findings obtained from the study coincide with the findings of previous similar studies (eg Karadağ \& Özdemir, 2017), and new and different results were also revealed. In the light of these findings, important recommendations were presented to various stakeholders in the higher education institution (e.g., $\mathrm{Ph} . \mathrm{D}$ students, lecturers, institutions providing Ph.D education). According to current research results, faculty members teaching at the Ph.D level focus on students' deficiencies in academic writing and research methods and emphasize that this deficiency is an obstacle to quality publication. It is a remarkable finding that a similar question was also emphasized by students at the Ph.D level. In order to overcome the bilateral problem experienced, it is considered very important to give courses that support more academic writing, academic reading and research methods. It is expected that the education given at the $\mathrm{Ph}$.D level will be diversified with more academic development-oriented courses instead of theoretical courses.

According to the study's resuls, some courses appear to be included and almost with the same names in both undergraduate, graduate and Ph.D courses (eg, sustainable tourism). It is clear that this situation will not benefit a Ph.D level student. In this context, it is important is to improve and develop the Ph.D course pool and to focus more on research methods courses.

According to the findings, the students stated that they could not get full satisfaction from the quality of education during the Ph.D process. In this context, more comprehensive and efficient understanding of the process can be achieved with the academic support of the faculty members who undertake a guiding task for the Ph.D students. In addition to the academic support and benefit expected from the academicians, who are the pioneers of the academy, students should also focus on their individual academic development, and the expected benefit from the Ph.D process should be increased with more reading, research and focus of research methods. 


\section{Giriş}

Doktora; nitelikli insan gücüne ulaşmak, bilimin gelişmesine katkıda bulunmak ve akademiden elde edilen faydanın artmasını sağlamak açısından oldukça önemli bir süreçtir (Özmen ve Aydın Güç, 2013). Doktora öğreniminin bu denli önemi doğrultusunda gerek ulusal (Saracaloğlu, 2008; Özmen ve Aydın Güç, 2013; Limon ve Durnal1, 2018), gerekse uluslararası (Overall vd., 2011; Brush vd., 2013; Hill ve Conceição, 2020) alan yazında doktora deneyimi ve sürecine yönelik birçok disiplinde araştırma yapılmıştır. $\mathrm{Bu}$ araştırmalarda; doktora öğrenim sürecinde kazanılan beceriler (Karadağ ve Özdemir, 2017), doktora öğrenimindeki zorluklar ve zorluklarla baş etme yöntemleri (Özmen ve Aydın Güç, 2013; Shin vd., 2018; Seçer, 2021), doktora öğrencileriyle öğretim üyeleri arasındaki ilişkiler (Golde, 2000; Golde ve Dore, 2001; Orakc1, 2020; Seçer, 2021), doktora öğrencilerinin yeterlikleri (Karadağ ve Özdemir, 2017), kariyer beklentileri (McAlpine ve Turner, 2012), doktora öğrenimine yönelik motivasyon (Seçer, 2021), doktora tez sürecine yönelik sorunlar (Akbulut vd., 2013) ve doktora öğreniminin mevcut durumu (Brush vd., 2013) gibi konular araştırılmıştır.

Farklı bilim dallarında doktora eğitim sürecine yönelik yapılan araştırmalara karşın; turizm alan yazınında daha sınırlı bilgiye ulaşılmış olması, bu çalışmanın gerekliliğini ortaya koymaktadır (Okumus ve Yagci, 2006; Çakıc1, 2006; Li ve Qi, 2019; Qi ve Li, 2020; Li vd., 2021; Yazıt ve DemirdelenAlrawadieh, 2021; Ajanovic ve Çizel, 2021). Bu kapsamda Okumuş ve Yağcı (2006), Türkiye'de turizm alanında yükseköğrenimin mevcut durumunu tartışmakta ve Türkiye'nin turizmden daha fazla gelir elde edebilmesi için, yükseköğretim standartlarının arttırılmasının önemine değinmektedir. Qi ve Li (2020), turizm öğrencilerinin doktora sürecinde yaşadıkları zorluklara ilişkin algılarını ortaya koyarken; Yazıt ve Demirdelen-Alrawadieh (2021) de benzer olarak doktora düzeyinde turizm öğrencilerinin karşılaştıkları sorunları belirlemiştir. Bu kapsamda, doktora düzeyinde en çok ders müfredatı kaynaklı sorunlara dikkat çekilirken, sonrasında öğrenci ve akademi kaynaklı sorunlar belirlenmiştir. Ajanovic ve Çizel (2021), tez sürecindeki önem doğrultusunda turizmde disiplinler arası doktora tez yazarı olma ve doktora tezinde disiplinler arası düşüncenin bilgi üretimi açısından önemine değinmektedir. Son olarak Li ve Qi (2019) ise turizmde doktora yapan öğrencilerin yurtdışında neden bir doktora programını tercih ettiklerini ve bu tercih sırasındaki seçim kriterlerini (ör. kişisel nedenler, ülke imajı, üniversite imajı) ortaya koymaktadır. Söz konusu çalışmalar turizmde doktora sürecinin önemine dikkat çekse de, turizm alanında doktora öğrenim sürecine yönelik kapsamlı bir araştırma yapmak ve bu araştırmada gerek doktora öğrencilerinin, gerekse doktora düzeyinde ders veren öğretim üyelerinin görüşlerini almak oldukça önemli görülmektedir. Dolayısıyla bu çalışmada diğer çalışmalardan farklı olarak, hem öğretim üyelerinin, hem de öğrencilerin görüşlerini ortaya koyan kapsamlı ve bütüncül bir bakış açısı sunulmaktadir.

Turizmde doktora deneyimine yönelik çift taraflı bir görüş sunmak, süreci oluşturan en temel öğelerin (öğretim üyesi ve öğrenci) görüş ve düşüncelerini anlamayı kolaylaştırmaktadır. Aynı zamanda sürece yönelik ortak ve farklılaşan yönlerde sunulan görüş, doktora deneyiminden elde edilen faydanın ve yaşanılan sorunların daha net belirlenmesine yardımcı olmaktadır. Örneğin, bu çalışmanın bulguları arasında görüleceği gibi, doktora düzeyinde ders veren öğretim üyeleri, doktora öğrencilerinin akademik yazım ve yöntem konusundaki eksikliklerini vurgularken, doktora öğrencileri de aynı sorunu belirtmektedir. Dolayısıyla ortak görüşler ve bu görüşlere yönelik geliştirilen stratejiler sürecin iyileştirilmesine katkıda bulunabilir.

Alan yazında turizmde doktora öğrenimine yönelik çift taraflı görüş sunan çalışmalar oldukça sınırlıdır (ör. Çakıcı, 2006). Sınırlı olmasına karşın, söz konusu çalışmada tez danışmanı seçme, danışman hakkında görüş sunma ve danışmanın da öğrenci açısından görüş sunması gibi tez sürecine yönelik konular araştırıldığı için (Çakıcı, 2006), doktora sürecinde yer alan öğretim üyesi ve öğrenciler açısından daha kapsamlı ve detaylı bir araştırma gerekliliği doğmuştur. Bu anlamda, hâlihazır çalışma turizm alanında doktora yapan öğrencilerin eğitim deneyimini ortaya koyarken, öğrencilerin doktora öğrenimine yönelik görüş ve düşüncelerini de belirlemektedir. Aynı zamanda çalışma, bu alanda ders veren öğretim üyeleriyle öğrenciler arasındaki ilişkiyi ve öğretim üyelerinin bakış açısından bir doktora öğrencisinden beklentileri de belirlemektedir. Son olarak çalışmanın, doktora eğitim deneyimine yönelik alan yazına katkı sunması beklenmekte, doktora eğitim sürecindeki tüm paydaşlara (ör. 
öğrenciler ve öğretim üyeleri) yönelik önerileriyle doktora öğrenimindeki etkinliği ve verimliliği arttırmayı hedeflemektedir.

\section{Literatür taraması}

Toplum refahının artması, bilginin yaygınlaşması ve ülkelerin kalkınmasında eğitimin oldukça önemli bir yeri bulunmaktadır (Karadağ ve Özdemir, 2017). Bu önem doğrultusunda alan yazında eğitim üzerine birçok araştırmaya rastlanmaktadır (Lam ve Xiao, 2000; Dale ve Robinson, 2001; Wang vd., 2010; Kopnina, 2020). Eğitimin her kademesi kişisel ve toplumsal gelişim açısından önemli olsa da özellikle lisansüstü eğitimin, gerek akademik kariyer, gerekse de sektörel başarı için eğitim-öğretim sürecinde önemli bir basamak olduğu söylenebilir.

Hemen hemen bütün bilim dallarında lisansüstü eğitime yönelik ilgi ve istek oldukça fazladır. Şahin ve arkadaşları (2011), birbirinden farklı bölüm ve üniversitelerde yapmış oldukları çok kapsamlı bir çalışmada, öğrencilerin yarısından fazlasının aldıkları lisans eğitimi sonrasında lisansüstü düzeyde eğitime başlama amacının olduğu sonucuna ulaşmıştır. Çalışmada yer alan katılımcıların üçte birinin ise, doktora öğrenimini hedefledikleri ortaya çıkmıştır. Bu sonuç, aslında Türkiye'de lisansüstü eğitime yönelik talebin oldukça yüksek olduğunun bir göstergesidir. Bu talebin akademide ilerlemek veya sektörde nitelikli işgücü olarak yer almak gibi birbirinden farklı amaçları olsa da (Arslan ve Boylu, 2014; Unur ve Köşker, 2015), bazı güncel çalışmalarda öğrencilerin lisansüstü eğitimi tamamlama konusundaki tutumunun da olumlu olduğu görülmektedir (Kahraman ve Demirdelen-Alrawadieh, 2021).

Doktora, Lisansüstü Eğitim ve Öğretim Yönetmeliği'nde şu şekilde tanımlanmıştır: “Doktora programı, öğrenciye bağımsız araştırma yapma, bilimsel problemleri geniş ve derin bir bakış açısı ile irdeleyerek yorum yapma, analiz etme ve yeni sentezlere ulaşmak için gerekli becerileri kazandırır" (resmigazete.gov.tr, 01.08.2021). Bir diğer ifadeyle doktora öğrenimi; akademiye giriş yapmak, bireylerin alana özgü bilgisini geliştirmek, bilimsel çalışmalara odaklanmak, akademide ilerlemek (Özmen ve Aydın Güç, 2013; Unur ve Köşker, 2015; Aydemir ve Çam, 2015), bireysel açıdan kendini gerçekleştirmek (Sever ve Ersoy, 2017) ve toplum için saygınlık kazanmak (Aydemir ve Çam, 2015) gibi amaçlarla tercih edilmektedir.

Doktoranın bilim yolundaki en üst dereceyi ifade etmesi (Balc1, 2013) ve öğrenim yaşamının son dönemi olması itibariyle de önemi büyüktür. Doktoradan sağlanan fayda kişiden kişiye değişse de her bir birey için doktora eğitim sürecinin kaliteli ve verimli geçmesi oldukça önemlidir. Bu önem doğrultusunda, doktora eğitim sürecinde gerek öğrencilerin gerekse de doktora düzeyinde ders veren öğretim üyelerinin bazı istek ve beklentileri bulunmaktadır. Bu istek ve beklentilerin gerçekleşmemesi ve öğretim üyeleri ile öğrenciler arasındaki ilişkinin olumsuz yansımalarının olumsuz sonuçlar sunması tesadüf değildir.

Austin (2002), lisansüstü öğrenciler üzerine yaptığı araştırmada, öğretim üyelerinin öğrencilere destekleyici mentorluk sağlamalarının, onların akademik gelişimleri açısından önemini vurgulamaktadır. Bu kapsamda doktora öğrencilerine düzenli rehberlik ve önderlik etme, tavsiye ve önerilerde bulunma ve geri dönüt sunma verimlilik açısından önemli ve gereklidir. Fan ve arkadaşları da (2019), benzer şekilde doktora sürecinde yol gösterici ve destekleyici bir danışmanın önemli olduğunu savunmuştur. Sever ve Ersoy (2017) ise, danışman öğretim üyesinin doktora öğrencisine meslektaşı gibi davranması ve değer vermesi gerektiğini belirtmiştir. Ancak bu beklentilere karşın Qi ve Li (2020), öğretim üyelerinin ilgilenmesi ve denetlemesi gereken birçok doktora adayı olduğu ve bu durum sonucunda öğrencilere yeterince danışmanlık verilemediği sonucuna ulaşmıştır. Dahası öğretim üyeleri kendi kişisel projelerine ve makalelerine odaklandığından, doktora öğrencilerine ve doktora tezlerine sınırlı destek verildiğini belirtmiştir. Bu sınırlı destek, danışman öğretim üyesi ve doktora öğrencisi arasındaki ilişkiyi olumsuz yönde etkileyebilir. Danışman ile olumsuz ilişkiler ise lisansüstü düzeyde öğrencileri yıpratan en önemli sorunlardan biridir (Ertem ve Gokalp, 2019).

Carr ve Hayes (2017b), öğrencilerin iyi yayın yapma konusunda doktora yaptıkları üniversitenin teşvik edici olmasının önemi üzerinde durmuştur. Onlara göre bazı üniversiteler veya öğretim elemanları, öğrencilerini proaktif bir şekilde yayın yapmaya teşvik ederken, diğerleri inisiyatifi öğrencilere bırakma 
eğiliminde olabilmektedir. Ancak öğrencilerin başarıyı elde etme ve özgeçmişlerini güçlü araştırmalarla zenginleştirmesi için teşvik edilmesi gerektiği sonucuna ulaşmışlardır. Bu teşvik zaman zaman bazı nedenlerle gerçekleşemeyebilir. Örneğin, öğretim üyelerinin akademik iş yükünün fazlalığı, doktora sürecindeki öğrencilerin yaşayabileceği problemler arasında oldukça önemli bir bulgudur (Karadağ ve Özdemir, 2017).

Öğrenciler açısından doktora öğrenimi ve beklenen fayda ne denli önemliyse, sürecin diğer tarafında bulunan öğretim üyeleri de doktora öğrencilerine ve turizm eğitimine yönelik bazı beklentiler içerisindedir. Örneğin, öğrencilerin doktora sürecinde yetersiz ve bilgiden yoksun olmasının (Golde ve Dore, 2001), öğretim üyeleri açısından da bazı zorlukları beraberinde getirmesi muhtemeldir. $\mathrm{Bu}$ kapsamda, doktora düzeyindeki öğrencilerin bilimsel araştırma ve alan bilgisine hâkim olması, kendini iyi bir şekilde ifade edebilmesi, üst düzey düşünme ve iletişim açısından yeterli olması (Karadağ ve Özdemir, 2017) ve disiplinler arası bakış sunması (Ajanovic ve Çizel, 2021) beklenmektedir.

Doktora, uzun ve zaman zaman yorucu bir süreç olarak görülmektedir. Dolayısıyla bu süreçte bilimsel gelişimin önünde bazı zorlu yollar bulunabilir. Ancak, doktoradaki zorluklarla baş etme yöntemleri de birçok araştırmada ortaya konulmuştur (Shin vd., 2018; Qi ve Li, 2020; Yazıt ve DemirdelenAlrawadieh, 2021). Bu zorlu yolların üstesinden gelebilmede akademik sabır da oldukça önemlidir. Kıral (2019), akademik yaşamda sabır konusunu araştırmış ve doktora öğrencilerinin bazı öğretim üyelerinin olumsuz davranışlarına ve onlara hayır diyememe konusuna, doktora sürecindeki zaman baskısına, akademik çalışmalarda yaşanan aksaklıklara sabır gösterildiği sonucuna ulaşmıştır.

Doktora öğrenimi, her ne kadar bütün bilim dalları için önemli olsa da, hizmet sektörü olan turizm açısından da önemi son derece büyüktür. Turizm alanında doktoranın amacı; sektörün güncel sorunlarını çözen, sektöre yönelik kavrama ve karar verme yetkisine sahip olan bilim insanları veya yöneticileri yetiştirmektir (Arslan ve Boylu, 2014). Turizm alanında doktora yaklaşık 45 yıldır devam etmekte (Okumus ve Yagci, 2006) ve doktora öğrenimine verilen önem ile günümüzde turizm alanında doktora düzeyinde eğitim veren 20'den fazla üniversite bulunmaktadır (yok.gov.tr, 01.03.2021). Turizmde doktora öğreniminin köklü tarihi ve eğitim veren kurumların nicel değeri fazla olmasına karşın; turizm alanında az sayıda çalışma doktora deneyimini ve sürecin zorluklarını araştırmıştır (ör. Çakıcı, 2006; Yazıt ve Demirdelen-Alrawadieh, 2021). Bu çalışmalardan birinde turizm alanında yüksek lisans ve doktora düzeyinde tez hazırlamış öğrencilerin danışman öğretim üyelerini değerlendirilmeleri beklenmiş ve sonuç olarak danışman öğretim üyelerinin istatistiki analiz ve nicel konulardaki zayıf noktaları ortaya konulmuştur. Öte yandan aynı çalışmada danışman öğretim üyeleri de yüksek lisans veya doktora düzeyindeki öğrencileri değerlendirmiştir. Sonuç olarak, öğrencilerin doktora sürecinde istatistik bilgisi ve araştırma yöntemleri konularındaki eksiklikleri vurgulanmıştır (Çakıcı, 2006). Bu sonucun çift taraflı bakış açısıyla benzer noktalara vurgu yapması oldukça önemli bir sonuçtur. Benzer şekilde Yazıt ve Demirdelen-Alrawadieh (2021), doktora düzeyinde turizm öğrencilerinin karşılaştıkları sorunları ortaya koymaya çalışmışlardır. Çalışmada turizm alanında doktora yapan öğrencilerin en çok ders müfredatına yönelik sorunları belirtilirken; araştırma yöntemleri, akademik yazım gibi konularda eksiklikler vurgulanmıştır.

Sop ve Kozak (2021) turizm akademisyenlerinin ve lisansüstü turizm öğrencilerinin yöntem bilgisinin önemine değinmiştir. Yazarlara göre, turizm araştırmacılarının yöntem ve tasarım konularına hâkim olması, başarılı ve nitelikli araştırmacı olmanın en temel kriterlerinden biridir. Zaten Sop (2007) çalışması da, genç turizm akademisyenlerinin araştırma süreçlerine yönelik oluşturulan faktörler içerisinde veri toplama sürecinden sonra en çok araştırma için uygulanacak yöntemi belirleme konusunda zorluk yaşadıklarını belirlemiştir.

Türkiye'de turizm eğitimine yönelik araştırmaların sayısı fazla olmasına karşın (Akoğlan-Kozak, 2009; Murat ve Bucak, 2012; Baltac1 vd., 2012; Daniel vd., 2017; Kim ve Jeong, 2018; Kırlar-Can vd., 2021), turizm alanında doktora programlarına yönelik çalışmaların sayıca az olması (ör. Li vd., 2021) bu çalışmanın önemini ortaya koymaktadır. Sonuç olarak bu çalışma, turizm alanında doktora öğrenimi veren öğretim üyeleriyle, turizm alanında eğitim alan doktora öğrencilerinin görüş ve düşüncelerini ortaya koymak amacıyla hazırlanmış olup, gerek alan yazına teorik katkı sunması, gerekse de bu süreçte 
öğretim üyeleriyle öğrencilerin beklentileri, deneyimleri ve yaşanılan zorlukların belirlenmesi açısından uygulamaya yönelik katkı da sunmaktadır.

\section{Yöntem}

Araştırmanın amacı, turizm alanında doktora öğrenimi veren öğretim üyeleriyle, turizm alanında eğitim alan doktora öğrencilerinin görüş ve düşüncelerini ortaya koymaktır. Bu amaçla, araştırmada nitel bir yaklaşım benimsenerek derinlemesine görüşmeler yapılmıştır. Doktoraya yönelik deneyimleri belirleyebilmek adına hem doktora düzeyinde ders veren akademisyenlere, hem de doktora düzeyinde ders alan öğrencilere yönelik soru formu oluşturulmuştur. Her iki form da doktora öğrenimine yönelik detaylı bir alan yazın taraması sonucunda oluşturulmuştur (Golde ve Dore, 2001; Çakıcı, 2006; Saracaloğlu, 2008; Limon ve Durnal1, 2018; Li ve Qi, 2019; Qi ve Li, 2020). Görüşme sorularının ilk kısmında; doktora öğrencilerinin yaş, cinsiyet, medeni durum, bir işte çalışıp çalışmadığı, doktora yaptığ 1 okul ve doktora bittikten sonraki hedefi ile ilgili sorular yer alırken; öğretim üyelerinin ise yaş, cinsiyet, doktora düzeyindeki deneyimi ve bağlı olduğu kurum ile ilgili sorular bulunmaktadır. Görüşme sorularının ikinci kısmında ise doktora deneyimini belirlemeye yönelik açık uçlu sorularla birlikte katılımcıların doktora deneyimine yönelik görüşlerine başvurulmuştur. Öğretim üyelerine yönelik oluşturulan soru formunda; öğretim üyelerinin doktora öğrencilerine ve turizm eğitimine yönelik bakış açıları, doktora öğrencilerinin sahip olmaları gereken özellikler, öğrencilerden beklentiler, öğrencilerle iletişim, danışman öğrenci ilişkisi, iyi yayın yapma ve akademik hayat üzerine sorular yer alırken; öğrencilere yönelik oluşturulan soru formunda; ders veya tez aşamasındaki öğrencilerin turizm eğitimine veya öğretim üyelerine yönelik algısı, turizm eğitimi sonrası beklentileri, danışman ve diğer öğretim üyeleriyle ilişkiler, doktoradan elde edilen fayda, iyi yayın yapma ve akademik beklenti üzerine sorular sorulmuştur.

Her iki gruptaki katılımcılar, Türkiye'de doktora düzeyinde eğitim veren birçok üniversiteyi kapsamaktadır. Bu okullar alfabetik siralamaya göre Adnan Menderes, Afyon Kocatepe, Akdeniz, Anadolu, Ankara Hacı Bayram Veli, Balıkesir, Çanakkale 18 Mart, Dokuz Eylül, İstanbul, Kocaeli, Mersin, Nevşehir Hacı Bektaş Veli ve Sakarya Üniversitesi'dir. Bu kapsamda gerek doktora öğrencileri, gerekse doktora düzeyinde ders veren öğretim üyeleri bilinçli olarak birbirinden farklı üniversitelerden seçilmiş olup, buradaki amaç veri çeşitliliği ve zenginliğini sağlamaktır. Ancak araştırma bulgularında söz konusu üniversite isimleri belirtilmemiştir. Bu durumun nedeni ise kurum veya kişilere yönelik oluşabilecek olumsuz algıların önlenme isteğidir. Çalışma yazarlarının her ikisi de öğretim elemanı olarak çalıştı̆ğından, veri toplama sürecinde öncelikle kolayda örneklem yöntemine başvurulmuş ve veriler araştırmaya katılmaya gönüllü kişilerden toplanmıştır. Ancak sayının yeterli olmaması nedeniyle kolayda örneklemin yanı sıra kartopu örneklem yöntemine de başvurulmuş ve araştırmaya katılan gönüllü kişilerin yönlendirmeleriyle diğer katılımcılara ulaşılmıştır. Süreç sonunda 20 doktora düzeyinde ders veren öğretim üyesi ve 20 doktora düzeyindeki turizm öğrencisi olmak üzere toplam 40 kişinin görüşlerine başvurulmuştur. Veri doygunluğuna ulaşıldığından bu sayının yeterli olduğu kanaati oluşmuştur (Glaser ve Strauss, 1967). Veri toplama süreci 1 Ağustos 2020 ve 3 Eylül 2020 tarihleri arasındaki süreyi kapsamaktadır. COVID-19 salgınının yoğun olduğu bu dönemde sosyal mesafe kurallarına uygun olarak tüm görüşmeler uzaktan (telefon veya zoom üzerinden) gerçekleştirilmiş olup, yapılan görüşmeler gerek akademisyenlerden, gerekse doktora öğrencilerinden alınan izinle kayıt altına alınmıştır. Bazı katılımcılar ise kayda izin vermediğinden, bu görüşmeler aynı anda görüşmeci tarafından yazıya dökülmüştür.

Her bir görüşme ortalama 20 dakika sürmüştür. Süreç sonunda elde edilen veriler içerik analizine tabi tutulmuş, toplanan zengin nitel verilerden Patton'un belirttiği şekilde (1990) ana ve ortak düşünceler ortaya konulmuştur. Bu düşüncelerin daha kapsamlı sunulabilmesi amaciyla doktora deneyimine yönelik birebir alıntılardan da faydalanılmıştır. İçerik analizinde, hem veriye dayalı (tümevarım), hem de teoriye dayalı (tümdengelim) olmak üzere karma bir yaklaşım benimsenmiştir (Dinçer ve Alrawadieh, 2017). Bu yaklaşım ile doktora öğrenimine yönelik mevcut alan yazın göz ardı edilmeden, elde edilen verilerden ortaya çıkan temaların doğalca oluşması sağlanmıştır (Patton, 1990). İçerik analizinin güvenirliğini sağlamak amacıyla veriler iki bağımsız araştırmacı tarafından analiz edilerek (Neuman, 2003; Lune ve Berg, 2017), oluşturulan son çerçeve üzerinde ortak görüş sunulmuştur. Bu 
araştırma kapsamında etik onay Sinop Üniversitesi İnsan Araştırmaları Etik Kurulu Başkanlığı’ndan (2020/93) alınmıştır.

\section{Bulgular}

Doktora eğitim deneyimini ortaya koymaya yönelik gerçekleştirilen bu araştırmada, turizmde doktora yapan öğrencilerden elde edilen demografik bulgular Tablo 1'de gösterilmektedir. Tabloya göre doktora öğrencilerinin çoğunluğu erkek ve bekârdır. Genel yaş ortalaması 29 olup, büyük çoğunluğu halihazırda zaten akademi içerisinde (öğretim görevlisi veya araştırma görevlisi) yer almaktadır. Akademinin dışında çalışan katılımcılar ise; otellerde, havayolu işletmelerinde veya turizm dışında başka bir meslekte görev almaktadır. Sadece tek bir katılımcı çalışmamaktadır. Söz konusu katılımcılar, yöntem kısmında belirtildiği üzere, Türkiye'de doktora düzeyinde eğitim veren birbirinden farklı üniversitelerdeki öğrencilerden oluşmaktadır. Son olarak, katılımcıların hepsi doktoradan sonra akademisyen olma fikrinde birleşmişlerdir.

Tablo 1: Turizm alanında doktora yapan öğrencilerin demografik özellikleri

\begin{tabular}{lllll}
\hline & & & Öğrenci Katılımcılar & \\
\hline Kod & Yaş & Cinsiyet & Medeni Durum & Çalışma Durumu/Unvan \\
Ö1 & 34 & Erkek & Bekâr & Konaklama işletmesinde çalışıyor \\
Ö2 & 27 & Erkek & Bekâr & Araştırma Görevlisi \\
Ö3 & 38 & Erkek & Evli & Havayolu işletmesinde çalışıyor \\
Ö4 & 26 & Erkek & Bekâr & Araştırma Görevlisi \\
Ö5 & 35 & Kadın & Evli & Ögretim Görevlisi \\
Ö6 & 32 & Kadın & Evli & Öğretim Görevlisi \\
Ö7 & 27 & Erkek & Bekâr & Ögretim Görevlisi \\
Ö8 & 29 & Kadın & Evli & Serbest Öğretim Elemanı* \\
Ö9 & 31 & Kadın & Evli & Öğretim Görevlisi \\
Ö10 & 26 & Kadın & Evli & Serbest Öğretim Elemanı* \\
Ö11 & 26 & Kadın & Bekâr & Yabanc1 dilde özel ders veriyor \\
Ö12 & 32 & Erkek & Bekâr & Öğretim Görevlisi \\
\hline O13 & 31 & Erkek & Evli & Öğretim Görevlisi \\
Ö14 & 28 & Kadın & Bekâr & Serbest Öğretim Eleman1* \\
Ö15 & 26 & Erkek & Bekâr & Araştırma Görevlisi \\
Ö16 & 27 & Kadın & Bekâr & Öğretim Görevlisi \\
\hline O17 & 28 & Erkek & Bekâr & Araştırma Görevlisi \\
Ö18 & 27 & Erkek & Bekâr & Konaklama işletmesinde çalışıyor \\
\hline Ö19 & 26 & Kadın & Bekâr & Çalışmıyor \\
Ö20 & 26 & Erkek & Bekâr & Öğretim Görevlisi \\
\hline
\end{tabular}

* İlgili öğrenciler, ders saati ücretli olarak çalışmaktadır.

Doktora düzeyinde ders veren öğretim üyeleri kapsamında elde edilen demografik bulgular Tablo 2'de gösterilmektedir. Tabloya göre, öğretim üyelerinin büyük çoğunluğu erkek ve orta yaş grubu katılımcılardan oluşmaktadır. Doktora düzeyindeki deneyimlerinin genel ortalaması yaklaşık altı yılı kapsamaktadır. Bu kapsamda öğretim üyelerinden bazıları uzun yıllar doktora düzeyinde ders verirken, henüz bu deneyime yeni ortak olmuş üç katılımcı bulunmaktadır. Tıpkı doktora öğrencileri gibi öğretim üyeleri de Türkiye'de doktora düzeyinde eğitim veren birbirinden farklı üniversitelerde çalışan katılımcı kitlesini oluşturmaktadır. 
Tablo 2: Doktora düzeyinde ders veren öğretim üyelerinin demografik özellikleri

\begin{tabular}{lllc}
\hline & \multicolumn{3}{c}{ Öğretim Üyesi Katılımcılar } \\
\hline Kod & Yaş & Cinsiyet & Doktora Düzeyindeki Deneyim \\
H1 & 42 & Erkek & 1 y1l \\
H2 & 45 & Kadın & 1 y1l \\
H3 & 56 & Erkek & 9 y1l \\
H4 & 57 & Erkek & 9 y1l \\
H5 & 49 & Erkek & 5 y1l \\
H6 & 44 & Kadın & 1 y1l \\
H7 & 51 & Erkek & 9 y1l \\
H8 & 46 & Kadın & 6 y1l \\
H9 & 53 & Erkek & 9 y1l \\
H10 & 53 & Kadın & 3 y1l \\
H11 & 49 & Kadın & 6 y1l \\
H12 & 58 & Erkek & 12 y1l \\
H13 & 47 & Erkek & 3 y1l \\
H14 & 49 & Erkek & 6 y1l \\
H15 & 48 & Erkek & 11 y1l \\
H16 & 43 & Erkek & 4 y1l \\
H17 & 46 & Kadın & 5 y1l \\
H18 & 39 & Erkek & 4 y1l \\
H19 & 43 & Erkek & 7 y1l \\
H20 & 48 & Kadın & 13 y1l \\
\hline
\end{tabular}

\section{Doktora düzeyinde ders veren öğretim üyelerinin bakış açısı}

Doktora düzeyinde ders veren öğretim üyelerinin doktora öğrencilerine yönelik görüşleri ortaya konulurken, öğrencilerinden memnun olduğunu belirten birçok görüş bulunduğu gibi, bu süreçte doktora öğrencilerinin eksiklerinin olduğunu vurgulayan görüşler de bulunmaktadır. Doktora öğrencilerinden memnuniyetini belirten (H3) görüşünü şu ifadeyle belirtmiştir:

"Uzun yıllardır doktora dersi veren bir ögretim üyesi olarak derslerimizi alan veya danışmanı olduğum çok sayıda ögrrencimiz olmuştur. Bunlar içerisinde çok azı ailevi ve diğer sebeplerden dolayı sorunlar yaşasa da genel olarak hepsi başarılı birer akademisyen görünümü vermişlerdir. Zaten şu anda eskiden danışmanı olduğum doktor öğretim üyelerimiz, doçentlerimiz, hatta profesörlerimiz mevcuttur...".

Olumlu görüşlerin yanı sıra, bazı eksiklerin varlığı da vurgulanmıştır. Özellikle doktora öğrencilerinin akademik eksiklikleri temel alınarak araştırma yöntemleri ve akademik yazım konusu vurgulanmış olup, sonrasında teori ve uygulamayı bağdaştırabilme konusundaki zorluk, ezber sisteminin kötü etkileri, öğrencilerin gelişime açık olmaması, okumaya ve araştırmaya yeterince zaman ayrılmaması, öğrencilerin araştırma-merak yönünün kuvvetli olmaması, ödevlerde gösterilen özensizlik, yabancı dil konusundaki eksiklik gibi sorunların varlığı dikkat çekmiştir. Örneğin (H18) genel olarak doktora öğrencilerinden memnun olduğunu belirtse de, bazı sorunların varlığına şu sözlerle dikkat çekmiştir: "Iyi dersem yalan olur ama kötü dersem de haksızlık etmiş olurum. Sadece çok çalışmaları gerekir diyeyim. Turizm ile ilgili derinlemesine yorum yapabilme noktasinda sorunlar var". Doktora öğrencilerinin araştırma yöntemleri konusundaki eksikliklerini vurgulayan (H11) bu konuda görüşünü şu şekilde ifade etmiştir. "...Daha fazla makale okuyup yöntem konusunda da kendilerini geliștirdikleri takdirde iyi çalışmalar yapabileceklerini düşünüyorum”. Sonraki başlıkta da görüleceği gibi, öğretim üyeleri gibi doktora düzeyindeki öğrenciler de araştırma yöntemleri konusunda benzer eksiklik ve sorunları belirtmiştir.

Öğretim üyeleri her ne kadar yöntem konusunda doktora öğrencilerine destek olduklarını belirtse de (örneğin, “....ÿ̈ntem konusunda üst düzey analizlerde takıldıkları noktalarda yol gösterici oluyorum...” H15); bazı katılımcılara göre yöntem konusundaki eksikliklerde öğretim üyelerinin de rolü bulunmaktadır. Bu kapsamda (H12) görüşünü şu şekilde belirtmiştir: “...Mutlaka biz hocaların da eksikleri olabilir. Özellikle yöntem konusundaki eksiklikler...”. Bu bulgu Sop ve Kozak'ın (2021) çalışmasıyla örtüşmektedir. Yazarlara göre, farklı üniversitelerde görev yapan ve farklı unvanlara sahip turizm akademisyenleri araştırma yöntemlerine hakimiyeti bir zorunluluk olarak görse de kendilerini büyük oranda bu konuda yetersiz bulmaktadır. Öğretim üyelerinin bu konudaki eksiklerini ortadan kaldırabilmesi, doktora öğrencilerine de daha verimli derslerin aktarılmasını sağlayacaktır. $\mathrm{Bu}$ 
kapsamda (H14) öğretim üyelerinin yöntem ile ilgili eksikliklerini vurgularken, araştırma yöntemleri öğrenebilmenin yolu olarak alınacak eğitimlerdeki teşviklerin de yetersizliğini belirtmiştir. “...Biz hocaların da yöntem ve yazım konularındaki eğitimlere katılabilmemiz için maddi ve manevi teşvik sistemi olmall. Maalesef mevcut durum buna pek imkân vermemektedir...".

Elde edilen bulgulardan hareketle, doktora öğrencilerinin akademik alt yapısını geliştirebilmesi için birtakım atılımları yapması gerekliliği ortaya çıkmıştır. Eğitim-öğretim hayatının son evresi olan doktoradan sonra birey artık öğrencilik yaşamını sonlandıracağı için, bu sürecin verimli geçmesi oldukça önemlidir. Bu nedenle, akademik anlamdaki gelişimlere odaklanılmalıdır. Bu kapsamda (H18) görüşünü şu şekilde belirtmiştir: "Doktora ögrencilerinin çoğu ezbere gidiyor. Yeterli oranda güncel çalışmaları takip etmiyorlar. Ödevleri özenerek yapmıyorlar. Sadece ödev teslim etmiş olmak için yapıyorlar...".

Şekil 1: Öğretim üyelerinin doktora öğrencilerine ve turizm eğitimine yönelik bakış açısı

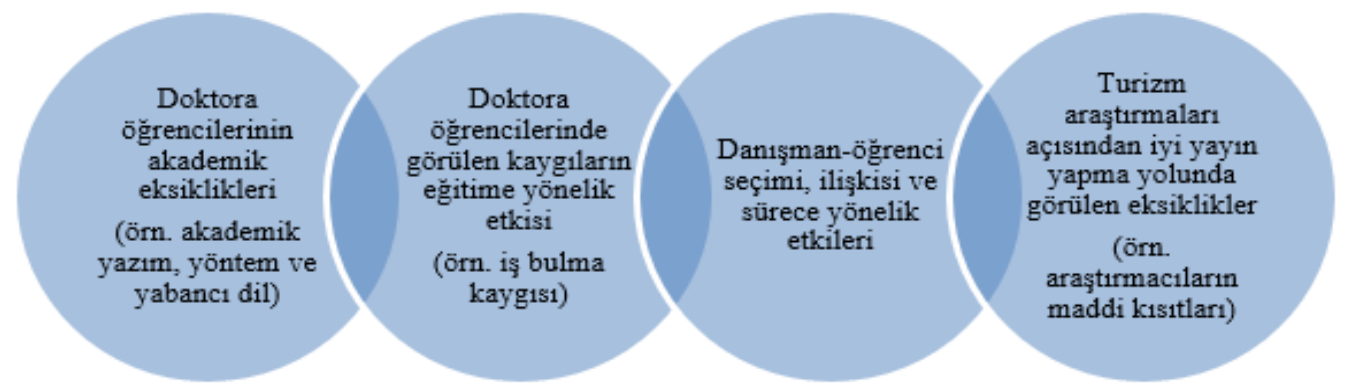

Öğretim üyeleri doktora yapan öğrencilerin mesleki zorlukları aşmak amacıyla da doktora yaptıklarını; iş bulma kaygısı, akademisyenliğin bir çıkış yolu veya iş alanı olarak görülmesi gibi zorlayıcı nedenlerin kaliteli araştırmacı olmanın önünde bir engel teşkil ettiğini belirtmiştir. Sayılan tüm bu nedenlerle doktora öğrencilerinin eğitim sürecine odaklanamaması, odaklansa dahi kişisel veya mesleki zorluklardan dolayı akademiye yeterince zaman ayrılmaması olası sorunları daha fazla büyütmektedir. Bu kapsamda (H9) görüşünü şu şekilde belirtmiştir: "Kalitenin her geçen yıl daha çok azaldiğg ve motivasyonların düşük olduğunu gözlemekteyim. Öğrencilerin işsiz oluşları, bir an önce işe girebilme, hayat koşuşturmalarındaki kaygılardan dolayı kendilerini doktora aşamasına yeterince veremedikleri kanaatindeyim. Kişisel beklentilerle kaliteli araştırmacı olunmaz”. Benzer bulgular bazı çalışmalarda da belirtilmiştir. Örneğin Yazıt ve Demirdelen-Alrawadieh (2021), doktora öğrencilerinin evli ve çocuklu olması gibi kişisel ve ailevi durumlarının kaliteli araştırmacı olmanın önünde bir engel olduğunu belirtirken; Aksatan ve arkadaşları ise (2020) kadın akademisyenlerin özellikle aile temelli rollerinin (ör. annelik süreci) mesleki zorluklara yol açtığını ve onların kariyerlerini etkilediğini belirtmiştir.

Doktora sürecinde danışman-öğrenci ilişkisi ve bu ilişkinin sürece yönelik etkisi de oldukça önemlidir. Çünkü doktoranın en önemli aşamalarından birisi de tez aşamasıdır. Ders dönemini ve yeterlik sürecini başarılı bir şekilde tamamlayan bir doktora öğrencisinin sonraki hedefi, tez dönemini de başarıyla tamamlamaktır. Bu aşamada danışman öğretim üyesi ve doktora öğrencisi arasındaki uyumun iyi olması tez sürecine de yansıdığından, doktora öğrencisinin danışmanını seçme hakkı sürecin daha kolay bir şekilde tamamlanması açısından önemlidir. Öğretim üyeleriyle yapılan görüşmelerde öğretim üyelerinin büyük bir kısmı, doktora öğrencilerinin danışman seçme hakkı olduğunu belirtmektedir. Bu kapsamda (H4) görüşünü şu şekilde belirtmiştir: "Öğrencinin danışman seçme hakkı kesinlikle olmalıdır. Yanlış tercih mutlaka düzeltilmelidir. Öğrenci-hoca uyumu çok önemli... Bizim kurumda sistem iyi kurgulanmıs ve bu özgürlüğ̈̈ kesin tanıyor”. Ancak buradaki sorun genellikle bir öğretim üyesinin üzerine tanımlanan doktora öğrenci sayısının, nicel açıdan fazla olmasından kaynaklanabilir. Çünkü olması gerekenden fazla öğrencinin olması, danışmanlığın da tam anlamıyla yapılamamasına ve verimin düşmesine neden olabilmektedir. Bu nedenle bazı katılımcılar şartlar el verdiği ölçüde öğrencilerin danışman seçme hakkı olduğunu belirtmiştir. "...Anabilim dalının imkânları da hocaların danışmanlık sayllarl da bu işi belirlerken önem arz ediyor. O nedenle dikkatli olmak gerekir” (H3). “...Bizim kurumda öğrencinin 3 ögretim üyesini seçmesi için dilekçe vermesi isteniyor ve öğretim üyesinin 
müsaitlik durumuna göre bir karar verilmesi planlanıyor..." (H1). Ancak nadir de olsa bazı katılımc1lar doktora öğrencilerinin danışman seçme hakkının olmadığını belirtmiş̧ir: “...Çok az öğrenci danışmanını seçme şansına sahip oluyor" (H6).

Sayılan tüm nedenlerin yanı sıra doktora düzeyinde ders veren öğretim üyelerinin doktora öğrencilerine yol gösterici olması da önemli görülmektedir. Dünyada saygın dergilerde kaliteli yayın yapma konusunda rekabet hızla artmaktadır. Bu artışın yanı sıra Türkiye'nin yağmacı yayıncılık konusunda ilk sıralarda yer alması (Demir 2018; Alrawadieh 2020) durumun endişe verici olduğunu doğrulamaktadır. Bu kapsamda öğretim üyelerine turizm araştırmaları açısından kaliteli yayın yapma ve Türkiye'nin bu konudaki eksikleri üzerine yöneltilen bir soruda akademisyenlerin büyük çoğunluğu bu durumun farkında olduğunu belirtmiş ve sorunların ortadan kaldırılmasına yönelik bakış açılarını ortaya koymuşlardır. İlginçtir ki, kaliteli yayın yapma konusundaki eksiklikler, birçok akademisyen tarafından benzer şekillerde ifade edilmiştir. Bu etkenler arasında yükselme kriterleri, teşvik sistemi, öğretim üyelerinin ders yükünün ve idari görevlerinin fazla olması, kişisel problemler, araştırma önündeki maddi kısıtlamalar, koşullar, yöntem ve akademik yazım konusundaki eksiklikler sıralanmıştır.

Sayılan bu etkenler, kaliteli yayın yapma konusundaki eksiklikler olarak bulunsa da, Alrawadieh ve Demirdelen-Alrawadieh (2021) çalışmasında Türkiye'deki teşvik sisteminin ve atama ölçütlerinin yayın sayısını arttırdığını belirtmiştir. Bu kapsamda (H2) görüşünü şu şekilde belirtmiştir: "Sosyal bilimler alanında kaliteli yayın yapmada Türkiye'nin yerini değerlendirirken bulunduğumuz yeri tanımlamak çok daha doğru olacaktır... Ne yazlk ki, son yıllarda teşvik sistemi, akademik yükselme vb. alanlarda niteliksel gelişimden çok niceliksel gelişime yönelik düzenlemelerin olduğunu görüyoruz”. Söz konusu bulgulara karşın kaliteli yayın algısında Türkiye'nin geri kalmadığını belirten akademisyenler de nispeten az olsa da bulunmaktadır. Örneğin (H12) görüşünü şu şekilde belirtmiştir: "Yayın yapma sayılarl göz önüne alındı̆̆ında geride gibi görünebiliriz. Fakat nitelik yönünden kötü konumda değiliz... ". Ancak görüşün gerçekçi olmadığı alan yazındaki bulgularla desteklenmektedir (Kurt, 2018). Dahası yayınlanan çalışmaların kalitesini olumsuz yönde etkileyen birçok sorunun (ör. çeşitli sebeplerle yazar olma baskısı, eleştirel bakış açısının eksikliği) var olduğu da bazı araştırmalarda vurgulanmıştır (McKercher, 2018).

\section{Doktora düzeyindeki turizm öğrencilerinin bakış açısı}

Araştırma kapsamında öncelikle öğrencilerin neden turizmde doktora öğrenimini seçtikleri yönünde görüşleri alınmıştır. Farklı görüşler olsa da, sonuç ortak paydada birleşmektedir: 'Akademisyen olmak'. $\mathrm{Bu}$ kapsamda doktora öğrencileri "eleş̧tirel bir bakış açısı kazanmak" (Ö3), "bilimsel anlamda gelişmek" (Ö4), "alanda uzmanlaşmak" (Ö7), "sektördeki tecrübeleri akademiye aktarmak" (Ö7), "araştırma yöntemlerine hâkim olmak" (Ö10), "akademik hayatta ilerlemek" (Ö18) gibi söylemlerle doktora öğreniminden beklentilerini belirtmişlerdir. Ancak sonuçlar arasında şaşırtıcı bulgular da göz önüne alınmalıdır. Mesleki zorluklardan dolayı akademiyi seçtiğini dile getiren (Ö5) görüşünü şu sözlerle belirtmiştir. “...Turizmde lisans döneminde sektörle karşılaştım ve sektör koşullarının kadınlara göre ă̆ır olduğunu fark ettim. O yüzden ne yapıp edip akademisyen olmam gerektiğini düşündüm. Çünkü bir kadın olarak sektörde çalışıp, aile hayatı kurup devam ettirebilmek çok zor”. Bu ve bunun gibi benzer bulgular, yukarıda belirtildiği gibi öğretim üyelerinin öğrencileri değerlendirirken gelecek kaygısı yönündeki sözlerini doğrular niteliktedir.

Elde edilen bulgulara göre doktora öğrencileri yüksek oranda öğretim üyelerinden ve aralarındaki ilişkiden duydukları olumlu duygulanımları belirtmiştir. Onlara göre öğretim üyeleri, doktora sürecinde onlarla destekleyici, samimi ve yönlendirici bir diyalog içerisindedir. Yapılan görüşmelerde "ilgili ve yardımsever" (Ö17), "Kariyer gelişim noktasında yönlendirici" (Ö7), "yalnızca akademik anlamda değil, hayatın hemen hemen çoğu alanında destekleyici” (Ö2) gibi ifadeler kullanılarak aralarındaki uyumu dile getirmişlerdir. Benzer şekilde danışman öğretim üyesi ile ilişkilerde de yüksek oranda memnuniyet bulunmaktadır. Hâlihazırdaki araştırmada iki öğrenci ders döneminde olmasından ve dört öğrenci de henüz tez aşamasına yeni geçtiğinden dolayı danışman ile ilişkiler konusunda fikir beyan edemezken; diğer katılımcılar danışmanlarıyla ilişkilerinin iyi olduğunu belirtmektedir. Bu kapsamda (Ö2) görüşünü şu sözlerle belirtmiştir: “...Açıç̧a söylemeliyim ki danışmanımın bunca yoğunluğuna rağmen beni bir kez bile geri çevirmemesi motivasyonumu arttırmaktadır”. Ancak olumlu görüşlere 
rağmen birçok öğrenci danışmanın geç dönüş yapması konusundaki sıkıntılarını da dile getirmişlerdir. "Hocalarla ilişkim iyi. İletişimimiz samimi ve sıcak. Fakat hocaların yapılan ödevlere ya da tezde yapılanlara kısa süre içerisinde dönmemeleri bazen motivasyonu düşürebiliyor" (Ö12). Mevcut bulgular her ne kadar danışman ile öğrenci arasındaki uyumun iyi olduğunu ortaya koysa da, bu ilişkide iletişimin de güçlü olması gerektiğini ve güçlü iletişimin de sürecin başarısında oldukça önemli etkenlerden biri olduğunu doğrulamaktadır.

Şekil 2: Doktora öğrencilerinin öğretim üyelerine ve turizm eğitimine yönelik bakış açısı

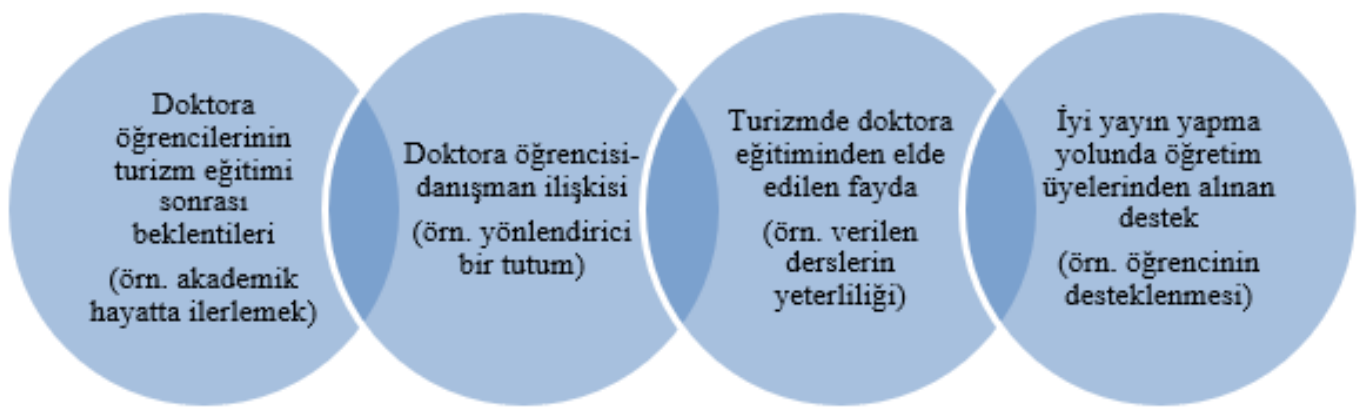

Mevcut bulgular, doktora düzeyinde alınan eğitimden elde edilen faydanın çok yönlü olduğunu doğrularken; bu süreçte tüm öğrencilerin hemfikir oldukları söylenemez. Özellikle bu süreçte elde edilen faydayı ve alınan eğitim kalitesini ortalama veya ortalamanın altında olarak değerlendirenlerin oranı oldukça yüksektir. Bir diğer ifadeyle bulgular, doktora düzeyinde verilen turizm eğitiminin iyileştirilmesi görüşünde birleşmiştir. "Kaliteli değildi. Araştırma yöntemleri dersi çok yetersizdi. Dersler yüksek lisansın tekrarıydl" (Ö5). "Kesinlikle aldı̆̆ım eğitim kötü değil, daha iyi olabilirdi. Yöntem konusunda derslerde daha fazla uygulama yapıp, derslerimiz Ingilizce işlenebilseydi çok daha iyi olacă̆ını düşünüyorum” (Ö4).

Araştırmada doktora öğrencilerine tıpkı öğretim üyelerine sorulan benzer bir soru sorularak kaliteli araştırma yapmak için (ör. Social Sciences Citation Index bir dergide) öğretim üyelerinden destek alıp almadıkları veya yönlendirilip yönlendirilmedikleri konusunda görüş bildirmeleri beklenmiştir. Bulgular doğrultusunda öğrenci katılımcıların büyük çoğunluğu bu konuda destek almadıklarını belirtmiştir. İlginç bir şekilde katılımcılar yüksek oranda bu tarz yayınları yapabilmek için zamanlarının kalmadığını ve doktora döneminin çok yoğun geçtiğini belirtmişlerdir. Bu kapsamda (Ö4) görüşünü şu sözlerle belirtmiştir: "Her derste kongrelere veya bir dergiye göndermek üzere mutlaka bir çalışma yapmamız isteniyor. Bu, her dönemde beş çalışma demek oluyor. Altı ay gibi kısa bir sürede çok kaliteli bir çalışma yapabilmemiz mümkün olmuyor". Bu durumun ortaya çıkışında ve bilimsel faaliyetlerde görülen hızlı artışta akademik teşvik ödeneklerinin etkili olduğu yapılan araştırmalarda doğrulanmaktadır (Ültay ve Ültay, 2018; Alrawadieh ve Demirdelen-Alrawadieh, 2021). Hatta Alrawadieh ve Demirdelen-Alrawadieh (2021), turizm alanında mevcut dergilerin çoğunun (yüzde 74) akademik teşvik ödeneği yönetmeliği ile ortaya çıktığını ve dergi sayılarındaki artışta talebin etkili olduğunu belirtmiştir. Benzer şekilde, öğretim üyelerinin kaliteli yayın yapma konusunda henüz doktora öğrencilerini hazır görmedikleri yönünde görüşler de bulunmaktadır. Ancak bu gerçekçi bir bakış açısı değildir. Her bir öğretim üyesi için doktora sürecindeki bir öğrenciyi desteklemek ve sürece hazır hale getirebilmek genel gaye olmalıdır. Dahası, kaliteli dergilerde yayın yapan her kişi, en üst akademik unvana sahip olmadığı gibi, lisansüstü eğitime yeni başlamış bir bireyin dahi saygın dergilerde yayınları olduğu-olabileceği bilinmelidir. Bu kapsamda (Ö18) "Hocalarımız bu tür yayınlardan bahsediyorlar, fakat bu yayınların zamanla ve tecrübe kazandıktan sonra yapılabileceğini söylüyorlar" sözleriyle süreci betimlemiştir. Saracaloğlu (2008), lisansüstü öğrenciler üzerine yapmış olduğu çalışmada araştırma deneyimi ile akademik güdülenme arasında anlamlı bir ilişki olduğunu belirlemiştir. Bir diğer ifadeyle doktora öğrencilerinin akademik anlamda güdülenmesi oldukça önemlidir. Sayılan tüm bu olumsuzlukların yanı sıra bu süreçte sayıca az da olsa memnuniyetini belirten ögrenciler de bulunmaktadır. "Derslerimize giren hocalarımızdan sadece bir tanesi bizi hep yönlendiriyor. Özellikle makale yazımı ve akademik yazım konularında bizi aydınlatıyor" (Ö15). Bu bulgudan hareketle bahsi geçen öğretim üyesinin gerek Scopus, gerekse de Web of Science makale sayısı ve h-indeks siralaması 
ile Türkiye'de ve dünyada turizm alanında en değerli öğretim üyelerinden biri olması tesadüf değildir. Bir diğer ifadeyle uluslararası anlamda saygın dergilerde deneyimi olan öğretim elemanlarının, ögrenciyi yönlendirme ve destekleme konusunda daha aktif olduğu anlaşılmaktadır.

Son olarak, turizmde doktora yapan öğrencilere yurtdışında eğitim alma isteğiyle ilgili bir soru yöneltildiğinde büyük çoğunluğu başka ülkelerde eğitim almak istediklerini belirtmiştir. Bu durumun başlıca nedenleri arasında ise yabancı dili iyi kullanabilme becerisi, akademik yazım ve araştırma yöntemlerinde etkin beceri, eğitim kalitesinin farklı olduğu yönündeki bakış, başka bir kültürü öğrenme gibi amaçlar bulunmaktadır. Bu sonuç Li ve Qi (2019) çalışmasından elde edilen bulguları destekler niteliktedir. Onlara göre, doktora düzeyindeki turizm öğrencileri kendi ülkelerinde kapasite ve firsat eksikliği, düşük eğitim kalitesi, ülkelerinde yaşanan siyasi ve ekonomik sorunlar gibi itici; eğitim kalitesi, ülkenin itibarı, İngilizce dil becerilerini geliştirme firsat1, farklı bir kültürü deneyimleme firsatı gibi faktörleri de çekici faktörler olarak sıralamıştır. Araştırmadan elde edilen bulgulara göre, az bir kısım ise doktora öğrenimini farklı şartlar dahi sunulsa değiştirmek istemediğini ve doktoraya yine aynı üniversitede devam etmek istediğini belirtmiştir.

\section{Sonuç ve öneriler}

Doktora düzeyinde turizm öğrencilerinin ve öğretim elemanlarının görüşlerine başvurularak ortaya konulan bulgular ile turizm alanında Türkiye'de doktora öğrenimi hakkında genel bir bakış açısı sunulmuştur. Çalışmadan elde edilen bazı bulgular, daha önce yapılan benzer çalışmaların ortaya koyduğu bulgularla örtüştüğü gibi (ör. Karadağ ve Özdemir, 2017), yeni ve farklı sonuçlar da ortaya konulmuştur. Bu bulgular 1şı̆̆ında da yükseköğretim kurumunda yer alan çeşitli paydaşlara (doktora öğrencileri ve öğretim elemanları) önemli tavsiyeler sunulmuştur.

Daha önce de belirtildiği gibi birçok farklı disiplinde ve turizm araştırmalarında doktora öğrencilerinin deneyimlerini, öğretim elemanları ile olan ilişkilerini, eğitim zorluklarını ve aldıkları eğitim kalitesine yönelik tutumlarını ele alan birçok çalışmaya rastlanmaktadır (Golde ve Dore, 2001; Akbulut vd., 2013; Karadağ ve Özdemir, 2017; Qi ve Li, 2001; Yazıt ve Demirdelen-Alrawadieh, 2021). Hâlihazır araştırma sonuçlarına göre ise doktora düzeyinde ders veren öğretim üyeleri, öğrencilerin akademik yazım ve araştırma yöntemleri konularındaki eksikliklerine odaklanmakta ve bu eksikliğin kaliteli yayın yapma konusunda bir engel olduğunu vurgulamaktadır. Benzer sorunun, doktora düzeyindeki öğrenciler tarafından da vurgulanmış olması dikkat çekici bir bulgudur. Yaşanan çift taraflı sorunun üstesinden gelinebilmesi için daha çok akademik yazım, akademik okuma ve araştırma yöntemlerini destekler nitelikteki derslerin verilmesi oldukça önemli görülmektedir. Benzer sonuç, Çakıcı (2006) çalışmasında da ortaya konulmuştur. Yazara göre, öğretim elemanları doktora öğrencilerini, doktora öğrencileri de öğretim elemanlarını araştırma yöntemleri konusunda diğer konulara nazaran daha eksik bulmuşlardır.

Doktora düzeyinde verilen eğitimin teorik dersler yerine daha çok akademik gelişim odaklı derslerle çeşitlendirilmesi beklenmektedir. Doktora; eleştirel olabilme, bir sorunu bilimsel yöntemlerle ele alarak soruna çözüm bulma, alana katkıda bulunabilme, eleştirel okuyabilme ve yazabilme olarak tanımlanabileceğinden, öğrencilerin önlisans ve lisans düzeyinde gördüğü standart derslerden ziyade; doktora sürecini, öğrencilerin sorun bulma ve araştırma yeteneğini geliştirebilmesine ve bunu bilimsel yöntemlerle tartışabilmesine olanak sağlayan ders ve ödevlerle çeşitlendirmek gereklidir.

Araştırmada bazı derslerin gerek lisans, gerek yüksek lisans ve gerekse de doktora derslerinde birebir ve aynı isimle yer aldığı belirlenmiştir (ör. sürdürülebilir turizm). Bu durumun ise, doktora düzeyindeki bir ögrenciye fayda getirmeyeceği açıktır. Bu kapsamda esas olan, yaşanan benzer eksikliklere karşın, doktora ders havuzunun iyileştirilmesi, geliştirilmesi ve doktora öğreniminde daha fazla araştırma yöntemleri derslerine odaklanılmasıdır. Bu sayede çift taraflı bir doyum gerçekleşebilir. Araştırma yöntemleri dersleri eklenmelidir ancak bu derslerin yanı sıra bilim felsefesine yönelik derslerin de müfredata eklenmesi, okutulan programın daha sağlam ve güçlü temellere dayandırılması açısından önemli ve gereklidir.

Bir diğer bulgu, doktora döneminin yoğun ve zorlayıcı geçtiği üzerinedir. Doktoranın amacı, "bilimsel problemleri geniş ve derin bir bakış açısı ile irdeleyerek yorum yapma ve analiz etme" 
(resmigazete.gov.tr, 01.08.2021) olarak tanımlansa da, öğretim üyeleri tarafindan bu süreçte her bir ders için yayın yapma zorunluluğu, sürecin yeterince verimli geçmemesine ve öğrencilerin kaliteden ziyade çeşitli baskılarla yayın yapmasına neden olabilmektedir. Öğrencinin görevi yayın yapmak değil, akademik gelişimine odaklanmaktır. Özellikle de zorunlu sebeplerle yayın yapmak, kişiyi akademiden uzaklaştırabilir. Kıral (2019), doktora öğrencilerinin öğretim üyelerine hayır deme korkusundan dolay1 bazı baskılara sabır göstermek zorunda kaldığını belirtmektedir. Dolayısıyla, öğrencileri zorunda tutmaktan ziyade teşvik etmek önerilmektedir. Carr ve Hayes (2017b) de çalışmasında, doktora öğrencilerinin yayın için teşvik edilmesi gerekliliği üzerinde durmaktadır.

Elde edilen bulgulara göre öğrenciler, doktora sürecinde eğitim kalitesinden tam anlamıyla doyum elde edemediklerini belirtmişlerdir. Bu sonuç benzer çalışmalarla da doğrulanmaktadır (ör. Karadağ ve Özdemir, 2017). Bu kapsamda, yol gösterici bir görev üstlenen öğretim üyelerinin doktora öğrencilerine yönelik verecekleri akademik destek ile sürecin daha kapsamlı ve verimli işlenmesi sağlanabilir. $\mathrm{Bu}$ kapsamda öğretim üyelerinin ve özellikle de danışmanların iyi bir rehber niteliğinde öğrencileri yönlendirmesi oldukça önemlidir. Bir diğer ifadeyle danışman, öğrencinin bilimsel bir kimlik kazanmasında yol gösterici olmalıdır. Doktora düzeyinde ders veren bir akademisyenin gerek mevcut alan yazına yön verebilmesi, gerekse doktora düzeyindeki öğrencilerine kaliteli bir akademisyen olma yolunda bakış açısı sunabilmesi için mevcut sorunların bilincinde olması ve sorunları ortadan kaldırmaya yönelik atılımları yapması önemli bir meseledir. Ulusal alan yazında söz sahibi olan öğretim üyelerinin uluslararası alan yazında ve saygın dergilerde de yayın yapması, doktora öğrencileri açısından teşvik edici ve yol gösterici bir durumdur. Kaliteli yayınların kişinin akademik gelişimine fayda sağladığı açık olsa da, ülkelerin de akademik sıralamasında önemli bir yer tuttuğu unutulmamalıdır.

Elbette bu yolda, doktora öğrencilerine de çok fazla görev düşmektedir. Akademinin öncüsü olan öğretim üyelerinden beklenen akademik destek ve faydanın yanı sıra, öğrencilerin de bireysel olarak akademik gelişimlerine odaklanması, daha fazla okuma, araştırma ve analiz çalışmalarıyla doktora sürecinden beklenen faydanın artması sağlanmalıdır. Bir diğer ifadeyle, doktora öğrencilerinin eğitim kalitesinden doyum elde edememesi, eğitimin kalite ve verimliliğinden kaynaklanabileceği gibi; öğrencilerin kişisel bilgi ve beceri eksikliğinden de kaynaklanabilir. Golde ve Dore (2001) çalışmasında, birçok öğrencinin, doktoranın neyi gerektirdiği, sürecin nasıl işlediği ve bu sürecin nasıl daha etkili ilerleyeceği konularında yetersiz olduklarını vurgulamıştır.

Doktora sürecinin verimliliği açısından öğretim üyesi ve öğrencilerin karşılıklı beklentilerini belirlemek ve beklentilerle uyumlu bir şekilde sürecin tamamlanması son derece önemlidir. Özellikle Türkiye'nin turizm alanında önemli destinasyonlardan biri olması sebebiyle turizm eğitimine yatırım yapılması ve her seviyedeki turizm eğitiminin desteklenmesi gerekmektedir (Okumus ve Yagci, 2006). Bir araştırmada doktora öğrencilerinin tez çalışmaları için genellikle pazarlama, turist davranışı, destinasyon yönetimi ve sürdürülebilirlik konularına eğilim gösterdiği belirlenmiştir (Carr ve Hayes, 2017a). Oysaki turizm disiplinler arası bir alandır. Turizm araştırmalarının disiplinler arası doğası sayesinde farklı bilim dallarından faydalanmak eğitim sektöründe yer alan her bir paydaş için yeni bir bakış açısı sunabilir (Ajanovic ve Çizel, 2021). Turizmin disiplinler arası özelliğine yapılan vurgu ile turizm alanının diğer bilim dallarınca da tanıması ve turizm alanının gelişimi desteklenmektedir (ör. Sop ve Kozak, 2021). Dolayısıyla doktora öğrencilerinin gerek makale çalışmalarında gerekse de tez çalışmalarında sınırlı bir bakış açısına sahip olması yerine daha geniş bir yaklaşımla ilgilerini çeken konulara eğilim göstermesi önerilmektedir.

Son olarak, bu çalışmanın bulguları ele alınırken birtakım sınırlamaları göz önünde bulundurmak gerekmektedir. Öncelikle, araştırmanın ilk aşamalarında ümit edildiğinden farklı olarak, zengin veriler elde edilememiştir. Salgın nedeniyle görüşmelerin uzaktan yapılmış olması bu konuda önemli bir etken olabileceği gibi, özellikle öğretim elemanlarının katılım konusundaki isteksizliği zengin verilerin elde edilmesini zorlaştırmıştır. Ayrıca, veriler akademisyen olan çalışmanın yazarlarından biri tarafından toplanıldığı için, doktora öğrencileri okudukları kurum ve eğitim aldıkları öğretim elamanları ile ilgili görüş ve algıları ifade etme konusunda tereddüt etmiş olabilirler. Bir diğer konu salgının turizm eğitimini de ciddi oranda etkileyebileceği yönündeki görüşlerin varlığıdır (Demirdelen-Alrawadieh, 2021). Bu durum veri kalitesini etkilemiş olabilir. Çalışma bulguları Türkiye'de doktora sürecindeki 
mevcut durumu ortaya koysa da, çalışmanın farklı ülkelerde doktora yapan öğrenciler ve öğretim üyeleriyle tekrarlanması farklı sonuçları ortaya koyabilir ve alana farklı bir bakış açısı sunabilir. Dahası, bu çalışma turizmde doktora öğrenimine odaklandığından, sosyal bilimlerin farklı disiplinlerinde tekrarlanması da daha kapsamlı bir görüş sunulabilmesi açısından önerilmektedir. Gelecekte yapılacak araştırmalarda özellikle doktora sürecindeki zorluklar ve sorunlar değerlendirilirken, nitel araştırmaların yanı sıra nicel verilerle de zengin bilgi kaynağına ulaşılabilir.

\section{Kaynakça}

Akbulut, H. İ., Çepni, S. ve Şahin, Ç. (2013). Doktora tez sürecinde karşılaşılan problemlerin belirlenmesi: Eğitim Fakültesi örneği. Dicle Üniversitesi Ziya Gökalp Eğitim Fakültesi Dergisi, 20, 50-69.

Akoğlan-Kozak, M. (2009). Akademik turizm eğitimi üzerine bir durum analizi. Muğla Üniversitesi Sosyal Bilimler Enstitüsü Dergisi, 22, 1-20.

Aksatan, M., Gunlu, E. ve Kozak, M. (2020). Women academics in tourism: A cross-gender study in Turkey. International Journal of Tourism Research, 22(6), 711-725.

Ajanovic, E. ve Çizel, B. (2021). How interdisciplinarity helps knowledge production: Reflections on a doctoral dissertation. Journal of Hospitality, Leisure, Sport \& Tourism Education, 28, 100310.

Alrawadieh, Z. ve D. Demirdelen Alrawadieh (2021). Türkiye merkezli hakemli turizm dergileri üzerine bir inceleme. Anatolia Turizm Araştırmaları Dergisi, 32(1), 31-42.

Alrawadieh, Z. (2020). Publishing in predatory tourism and hospitality journals: Mapping the academic market and identifying response strategies. Tourism and Hospitality Research, 20(1), 72-81.

Arslan, E. ve Boylu, Y. (2014). Türkiye'deki turizm eğitiminin rakamsal gelişmeler açısından değerlendirilmesi. Gazi Üniversitesi Turizm Fakültesi Dergisi, 1, 79-97.

Austin, A. E. (2002). Preparing the next generation of faculty: Graduate school as socialization to the academic career. The Journal Of Higher Education, 73(1), 94-122.

Aydemir, S. ve Çam, Ş. S. (2015). Lisansüstü öğrencilerinin lisansüstü eğitimi almaya ilişkin görüşleri. Türk Eğitim Dergisi, 4(4), 4-16.

Balc1, A. (2013). Doktora programı: Türk üniversiteleri doktora programları için bazı öneriler. Eğitim Bilimleri Araştırmaları Dergisi, 3(2), 1-20.

Baltacı, F., Üngüren, E., Avsallı, H. ve Demirel, O. N. (2012). Turizm eğitimi alan öğrencilerin eğitim memnuniyetlerinin ve geleceğe yönelik bakış açıların belirlemesine yönelik bir araştırma. Uluslararası Alanya İşletme Fakültesi Dergisi, 4(1), 17-25.

Brush, C. G., Duhaime, I. M., Gartner, W. B., Stewart, A., Katz, J. A., Hitt, M. A., Alvarez, S. A., Meyer G. D. ve Venkataraman, S. (2003). Doctoral education in the field of entrepreneurship. Journal of Management, 29(3), 309-331.

Carr, N. ve Hayes, S. (2017a). An analysis of trends in Ph.D. research in tourism. Tourism Recreation Research, 42(1), 32-44.

Carr, N. ve Hayes, S. (2017b). A comparison of tourism PhD Students' publication records and university of study. Tourism Management Perspectives, 23, 151-153.

Çakıcı, A. C. (2006). Turizm alanında lisansüstü tez hazırlayan öğrencilerin danışman öğretim üyelerini ve danışman öğretim üyelerinin de öğrencileri değerlendirmesi. Dokuz Eylül Üniversitesi Sosyal Bilimler Enstitüsü Dergisi, 8(3), 74-104.

Dale, C. ve Robinson, N. (2001). The theming of tourism education: A three-domain approach. International Journal of Contemporary Hospitality Management, 13(1), 30-34.

Daniel, A. D., Costa, R. A., Pita, M. ve Costa, C. (2017). Tourism education: What about entrepreneurial skills?. Journal of Hospitality and Tourism Management, 30, 65-72.

Demir, S. B. (2018). Predatory journals: Who publishes in them and why?. Journal of Informetrics, 12(4), 1296-1311.

Demirdelen Alrawadieh, D. (2021). Does employability anxiety trigger psychological distress and academic major dissatisfaction? A study on tour guiding students. Journal of Tourismology, 7(1), 55-72.

Dinçer, M. Z. ve Alrawadieh, Z. (2017). Negative word of mouse in the hotel industry: A content analysis of online reviews on luxury hotels in Jordan. Journal of Hospitality Marketing \& Management, 26(8), 785-804. 
Ertem, H. Y. ve Gokalp, G. (2019). Role of personal and organizational factors on student attrition from graduate education: A mixed-model research. Journal of College Student Retention: Research, Theory \& Practice, 1521025119881391.

Fan, L., Mahmood, M. ve Uddin, M. A. (2019). Supportive Chinese supervisor, innovative international students: A social exchange theory perspective. Asia Pacific Education Review, 20(1), 101-115.

Glaser, B. G. ve Strauss, A. L. (1967). The discovery of grounded theory: Strategies for qualitative research. Aldine Publishing Company.

Golde, C. M. (2000). Should I stay or should I go? Student descriptions of the doctoral attrition process. The Review of Higher Education, 23(2), 199-227.

Golde, C. M. ve Dore, T. M. (2001). At cross purposes: What the experiences of today's doctoral students reveal about doctoral education, Madison: Eric Publishing

Hill, L. H. ve Conceição, S. C. (2020). Program and instructional strategies supportive of doctoral students' degree completion. Adult Learning, 31(1), 36-44.

Kahraman, O. C. ve Demirdelen Alrawadieh, D. (2021). The impact of perceived education quality on tourism and hospitality students' career choice: The mediating effects of academic self-efficacy. Journal of Hospitality, Leisure, Sport \& Tourism Education. 29, 100333.

Karadağ, N. ve Özdemir, S. (2017). Türkiye'de doktora eğitimi sürecine ilişkin öğretim üyelerinin ve doktora öğrencilerinin görüşleri. Yükseköğretim ve Bilim Dergisi, 7(2), 267-281.

Kıral, B. (2019). Akademik hayatta sabır üzerine nitel bir çalışma. Journal of Computer and Education Research. 7(14), 250-283.

Kırlar-Can, B., Ertaş, M. ve Kozak, M. (2021). Understanding the philosophy of tourism education: A perspective study in Turkey. International Journal of Tourism Research, doi.org/10.1002/jtr.2472.

Kim, H. J. ve Jeong, M. (2018). Research on hospitality and tourism education: Now and future. Tourism Management Perspectives, 25, 119-122.

Kopnina, H. (2020). Education for the future? Critical evaluation of education for sustainable development goals. The Journal of Environmental Education, 51(4), 280-291.

Kurt, S. (2018). Why do authors publish in predatory journals?. Learned Publishing, 31(2), 141-147.

Lam, T. ve Xiao, H. (2000). Challenges and constraints of hospitality and tourism education in China. International Journal of Contemporary Hospitality Management, 12(5), 291-295.

Li, F. S. ve Qi, H. (2019). An investigation of push and pull motivations of Chinese tourism doctoral students studying overseas. Journal of Hospitality, Leisure, Sport \& Tourism Education, 24, 9099.

Li, F. S., Qi, H. ve Guo, Q. (2021). Factors influencing Chinese tourism students' choice of an overseas PhD program. Journal of Hospitality, Leisure, Sport \& Tourism Education, 29, 100286.

Limon, İ. ve Durnalı, M. (2018). Doktora öğrencilerinin doktora eğitimi ve öğretim üyelerine yönelik metaforik algiları. Sakarya University Journal of Education, 8(1), 26-40.

Resmi Gazete. (2021). Lisansüstü Eğitim ve Öğretim Yönetmeliği. 01.08.2021 tarihinde https://www.mevzuat.gov.tr/File/GeneratePdf?mevzuatNo=21510\&mevzuatTur=KurumVeKuru lusYonetmeligi\&mevzuatTertip=5\#: :text=MADDE\%2015\%20\%E2\%80\%93(1)\%20Doktora,u la\%C5\%9Fmak\%20i\%C3\%A7in\%20gerekli\%20becerileri\%20kazand\%C4\%B1r\%C4\%B1r. adresinden erişildi.

Lune, H. ve Berg, B. L. (2017). Qualitative research methods for the social sciences. Pearson.

McAlpine, L. ve Turner, G. (2012). Imagined and emerging career patterns: Perceptions of doctoral students and research staff. Journal of Further and Higher Education, 36(4), 535-548.

McKercher, B. (2018). What is the state of hospitality and tourism research-2018?. International Journal of Contemporary Hospitality Management, 30(3), 1234-1244.

Murat, A. ve Bucak, T. (2012). Mesleki turizm eğitimi. Aksaray Üniversitesi İktisadi ve İdari Bilimler Fakültesi Dergisi, 4(2), 7-18.

Neuman, W. (2003). Social research methods: Qualitative and quantitative approaches. Allyn \& Bacon, Boston, MA.

Okumus, F. ve Yagci, O. (2006). Tourism higher education in Turkey. Journal of Teaching in Travel \& Tourism, 5(1-2), 89-116.

Orakc1, SS. (2020). Postgraduate students' expectations of their lecturers. The Qualitative Report, 25(1), 199-215. 
Overall, N. C., Deane, K. L. ve Peterson, E. R. (2011). Promoting doctoral students' research selfefficacy: Combining academic guidance with autonomy support. Higher Education Research \& Development, 30(6), 791-805.

Özmen, Z. M. ve Aydın Güç, F. (2013). Doktora eğitimi ile ilgili yaşanan zorluklar ve baş etme stratejileri: Durum çalışması. Yüksekögretim ve Bilim Dergisi, 3(3), 214-219.

Qi, H. ve Li, F. (2020). Understanding the study experience of Chinese tourism doctoral students studying overseas. Journal of China Tourism Research, doi.org/10.1080/19388160.2020.1772929.

Patton, M. Q. (1990). Qualitative evaluation and research methods. Sage.

Saracaloğlu, A. S. (2008). Lisansüstü öğrencilerin akademik güdülenme düzeyleri, araştırma kaygıları ve tutumları ile araştırma yeterlikleri arasındaki ilişki. Yüzüncü Yıl Üniversitesi Eğitim Fakültesi Dergisi, 5(2), 179-208.

Seçer, B. (2021). Akademisyen olmayanlar açısından doktora eğitimi. İzmir İktisat Dergisi, 36(2), 295313.

Sever, I. ve Ersoy, A. (2017). Araştırma görevlilerinin gözünden danışmanlık ve doktora süreçleri. Eğitim Bilimleri Araştırmaları Dergisi, Uluslararası E-Dergi, 7(1), 183-202.

Shin, J. C., Postiglione, G. A. ve Ho, K. C. (2018). Challenges for doctoral education in East Asia: A global and comparative perspective. Asia Pacific Education Review, 19(2), 141-155.

Sop, S. A. (2017). Turizm alanındaki araştırma görevlilerinin yayın performansı ve yayın yapmaya yönelik görüşleri. Turizm Akademik Dergisi, 4(1), 17-31.

Sop, S. A. ve Kozak, M. (2021). Araştırma yöntemleri bilgisinin önemi: Turizm alanına yönelik bir gömülü teori çalışması. Anatolia: Turizm Araştırmaları Dergisi, 32(2-Ön Yayımdaki Makaleler), 171-183.

Şahin, İ., Zoraloğlu, Y. R. ve Fırat, N. Ş. (2011). Üniversite öğrencilerinin yaşam amaçları, eğitsel hedefleri üniversite öğreniminden beklentileri ve memnuniyet durumları. Kuram ve Uygulamada Ĕ̈itim Yönetimi, 3(3), 429-452.

Unur, K. ve Köşker, H. (2015). Türkiye'de turizm eğitimi ve turizm eğitimi alan öğrencilerin turizme bakış açılarına yönelik araştırmaların incelenmesi. Çă̆ Üniversitesi Sosyal Bilimler Dergisi, 12(1), 44-71.

Ültay, E. ve Ültay, N. (2018). Akademik teşvik ödeneğinin bilimsel faaliyetlere etkisi hakkındaki akademisyen görüşleri. Yüksekögretim ve Bilim Dergisi, 1, 162-171.

Wang, J., Ayres, H. ve Huyton, J. (2010). Is tourism education meeting the needs of the tourism industry? An Australian case study. Journal of Hospitality \& Tourism Education, 22(1), 8-14.

Yazıt, H. ve Demirdelen Alrawadieh, D. (2021). Doktora düzeyinde turizm öğrencilerinin karşılaştıkları sorunlar üzerine bir araştırma. Avrasya Turizm Araştırmaları Dergisi, 2(1), 1-9.

Yükseköğretim Kurumu. (2021). Istatistikler. 01.03.2021 tarihinde https://istatistik.yok.gov.tr/ adresinden erişildi.

\section{Etik kurul onayı}

Sinop Üniversitesi İnsan Araştırmaları Etik Kurulu tarafından 2020 tarih ve 93 sayılı etik kurul onayı alınmıştır.

\section{Araştırmacıların katkı oranı beyanı}

Yazarlar çalışmaya eşit oranda katkı sağlamıştır.

Çıkar çatışması beyanı

Bu çalışmada herhangi bir potansiyel çıkar çatışması bulunmamaktadır. 